\title{
Investigation of Growth, Free Amino Acids, and Carbohydrate Concentration in the Roots of Perennial Ryegrass in Response to Soil Salinity at Subsurface Soil Depths
}

\author{
Zhuangjun Zhao \\ Key Laboratory of Plant Germplasm Enhancement and Specialty Agriculture, Wuhan Botanical \\ Garden, The Chinese Academy of Science, Wuhan City, Hubei, 430074, P.R. China \\ Margaret Mukami Gitau' ${ }^{1}$ \\ Key Laboratory of Plant Germplasm Enhancement and Specialty Agriculture, Wuhan Botanical \\ Garden, The Chinese Academy of Science, Wuhan City, Hubei, 430074, P.R. China; and College of \\ Life Sciences, University of Chinese Academy of Sciences, Beijing, China \\ Tao Hu, Yan Xie, Longxing Hu, and Jinmin Fu² \\ Key Laboratory of Plant Germplasm Enhancement and Specialty Agriculture, Wuhan Botanical \\ Garden, The Chinese Academy of Science, Wuhan City, Hubei, 430074, P.R. China
}

\begin{abstract}
Additional Index words. Lolium perenne, metabolic processes, physiological mechanisms, tolerance, adaptation
Abstract. Plants growing in salt-affected soils may have retarded growth and inhibited or altered metabolic processes. This study aims at investigating the impact of subsurface soil salinity on root growth and metabolic processes in perennial ryegrass (Lolium perenne). The seeds of perennial ryegrass (cv. Quick Start II) were planted in polyvinyl chloride (PVC) tubes $(10 \mathrm{~cm}$ diameter $\times 42 \mathrm{~cm}$ long) for 2 months. The experiment consisted of three treatments: 1) control, $40 \mathrm{~cm}$ filled with sand-peat mixture (7 sand : 3 peat wt/wt); 2) T20, a 20-cm-deep layer of saline soil covered with a 20-cm-deep layer of sand-peat mixture; and 3) T30, a 30-cm-deep layer of saline soil covered with a 10-cm-deep layer of sand-peat mixture. Our study showed that soil salinity at the subsurface inhibited the growth of perennial ryegrass roots. Compared with the control, the root activity in saline soil layer decreased, whereas it remained high in the mixture-soil zone. The content of amino acids in the roots obtained from the surface soil $(0-10 \mathrm{~cm})$ in T30 was greater than that in both the $\mathrm{T} 20$ and the control regimes. The content of soluble sugars in the roots went up with the decrease of the depth of sand-peat mixture. The increased root activity and free amino acids content in the roots sampled from the upper soil layers coupled with the increased soluble sugars in the roots subjected to soil salinity stress in the bottom soil layer represents some adaptive responses and regulative mechanisms in perennial ryegrass.
\end{abstract}

Soil and water salinity is a global problem in the 21 st century that threatens agricultural sustainability. In fact, the extent of salinized land is expanding at the rate of $10 \%$ per year and, experts speculate that by the year 2050 , more than $50 \%$ of the global arable land would be salinized (Shrivastava and Kumar, 2014). Inappropriate farming systems contribute to the largescale development of saline soil and massive loss of arable lands, especially in the arid and semiarid areas (Cheong and Yun, 2007). Soil salinity may have a profound impact on plant growth. Some studies have reported that salinization of soils inhibits the growth, development, and differentiation of plants and, causes low productivity of crops and grasses (Koca et al., 2007; Munns, 2002; Zhu, 2001). Salinity stress in bottommost soil is extremely frequent in the field; nonetheless, the upper soil may be sufficient for nutrient uptake by the plants if

Received for publication 26 Apr. 2016. Accepted for publication 14 July 2016. This research was financially supported by the science and technology service (STS) program (grant no. KFJ-EW-STS-120) of the Chinese Academy of Science.

${ }^{1}$ These authors contributed equally to this work.

${ }^{2}$ Corresponding author. E-mail: jfu@wbgcas.cn. accompanied by regular irrigation and remediation. However, the physiological mechanisms underlying plant adaptation to soil salinity at subsurface depth have not been adequately understood.

The high soil salinity due to neutral salts, such as $\mathrm{NaCl}$, has destructive effects on plant growth, development, and differentiation. Neutral salts mostly occur as a result of a neutralization reaction between a strong base and a strong acid or less often between a weak acid and a weak base. Neutral salts dissolve in water to form a solution of $\mathrm{pH} 7$ (Masterton et al., 2011). High $\mathrm{NaCl}$ content in soil affects plants through both the direct action of $\mathrm{Na}^{+}$and $\mathrm{Cl}^{-}$ions culminating in osmotic stress (Hasegawa et al., 2000; Munns, 2005). Soil salinity can disrupt ionic balance causing severe damage to plant roots (Hasegawa et al., 2000). Salinity also interferes with nutrient acquisition and hence causes micronutrient deficiencies in plants (Turkan and Demiral, 2009). The extent of damage resulting from salinity mainly depends on its influence on the plant's physiological and biochemical processes as well as the plant's ability to adapt to or tolerate salinity (Munns and Tester, 2008; Takahashi et al., 2001; Zhu, 2001). Patently, the root system is the first part of a plant to encounter and respond to high 
salinity environments. Therefore, plant roots have evolved several physiological and metabolic strategies to adapt to/ tolerate salinity stress to survive in saline conditions. For instance, plants adjust the content of free amino acids and modify carbohydrate metabolism to cope with stress.

Free amino acids are organic components essential for the synthesis of proteins and other growth substances. Therefore, they play a vital role in plants' stress tolerance through the modulation of stomatal conductance, detoxification of reactive oxygen species, and regulation of intracellular ion transport (Parida and Das, 2005; Rai, 2002; Szabados and Savoure, 2010). The accumulation of free amino acids enables osmotic adjustment a phenomenon speculated to improve plants' ability to cope with stress (Serraj and Sinclair, 2002). Furthermore, the buildup of free amino acids provides carbon and nitrogen for future use either under stress or less stressful environments (Greenway and Munns, 1980). About 18 free amino acids have been substantiated to have functions in plants' physiological and biochemical processes. Glutamic acid (Glu) and glycine (Gly) have been identified as the principal metabolites in the synthesis of chlorophyll (Kannangara et al., 1988). Proline has been considered to have the ability to stabilize the structure of proteins and membranes against adverse effects of drought, salinity, and extreme temperatures (Szabados and Savoure, 2010; Verslues and Sharp, 1999). Gly, arginine (Arg), asparagine, and serine (Ser) accrued in spinach (Spinacia oleracea) and coleus (Coleus blumei) subjected to salt stress (Di Martino et al., 2003; Gilbert et al., 1998). Asparagine and valine increased in bermudagrass (Cynodon dactylon) growing under water stress (Barnett and Naylor, 1966). Kerkeb and Kramer (2003), on the other hand, proposed that asparagine and histidine have the capacity to bind heavy metals hence acting as antidotes.

Carbohydrates synthesis in plants involves a series of complex reactions including photosynthesis. The growth, development, and differentiation of plants mainly depend on carbohydrate metabolism, which includes the synthesis of sucrose, fructose, and glucose (Hasegawa et al., 2000). High content of carbohydrates before and during abiotic stress in plants may, therefore, indicate better tolerance to stress (Kafi et al., 2003). Rolland et al. (2016) also put forward that the biochemical breakdown of carbohydrates can supply energy and metabolites to participate in biosynthetic processes. Soluble sugars, including glucose, fructose, and sucrose, have been considered as typical osmoprotectants and essential components for stabilization of cellular membranes. They also scavenge for radical reactive oxygen species besides serving as carbon storage components in plants (Farooq et al., 2009; Parida and Das, 2005; Rolland et al., 2006). The accumulation of free amino acids and carbohydrates may help in the following vital processes: maintenance of ionic balance in homeostasis, eradication of free radicals, stabilization of organelles and micronucleus, and the maintenance of the cytosol's acid-base balance pH (Gilbert et al., 1998). As of now, there is little information concerning the metabolic profiles of free amino acids and carbohydrates that influence plants' ability to cope with extreme soil salinity stress conditions, especially in perennial grasses.

Perennial ryegrass, native to western Europe, north Africa, and southwest Asia, is one of the most widely used cool-season turfgrasses in the northwest of China (Xiong et al., 2007). The rapid establishment of perennial ryegrass makes it suitable as a vanguard in combination with other turfgrasses on lawns, athletic fields, and golf courses (Xing et al., 2007). Furthermore, perennial ryegrass possesses desirable qualities including impressive regeneration, high density of tillers, excellent palatability and digestibility, high yield potential, and high protein content (Wilkins and Humphreys, 2003). As a result, it is a preferred perennial forage grass in the temperate regions of the world. However, there is limited information documenting the effect of extreme salinity stress, present in subsurface soil layers, on the physiological metabolisms in perennial ryegrass.

The first objective of this study was to analyze the effects of salinity present at subsurface soil layers on the root growth and root activity of perennial ryegrass. The second objective was to decipher salinity-induced changes of free amino acids and soluble sugars in the roots of perennial ryegrass exposed to extreme soil salinity. The final objective was to identify the suitable top-soil depth for root elongation and growth of perennial ryegrass exposed to salinity stress.

\section{Materials and Methods}

Plant materials and growth conditions. Saline soil came from the coast of Tianjin Tangku District (Tianjin, China) with $71,500 \mu \mathrm{S} \cdot \mathrm{cm}^{-1} \mathrm{NaCl}$. The soil's electrical conductivity (EC) was confirmed with the method described by Gupta (2001). The sand was sifted through a 20 -mesh sieve and mixed with peat in the ratio of $7: 3$. Peat served as the organic material with an $\mathrm{N}-\mathrm{P}-\mathrm{K}$ value of $\geq 2 \%$ as it appeared on the label. Perennial ryegrass (cv. Quick Start II) obtained from Wuhan Seed Co. (Wuhan, China) has a broad range of salinity adaptability, the utmost of salt tolerance level being $1.0 \%$ content of $\mathrm{NaCl}$.

Germination of $0.1 \mathrm{~g}$ of perennial ryegrass seeds was done in 15 PVC tubes (10.5 cm diameter, $42 \mathrm{~cm}$ depth), five tubes for each of the three treatments placed in a greenhouse. The first treatment (control) composed of tubes filled with a mixture of sand and peat to a depth of $40 \mathrm{~cm}$; saline soil was absent. The second treatment (T20) composed of tubes filled with a $20-\mathrm{cm}-$ deep layer of saline soil at the bottom and a 10-cm-deep mixture of sand and peat at the top. The third treatment (T30) composed of tubes containing a 30-cm-deep layer of saline soil at the bottom and a 10-cm-deep layer of the sand-peat mixture at the top. The daily air temperature was maintained at the range of 18 to $22{ }^{\circ} \mathrm{C}$, photosynthetic active radiation at $350 \mu \mathrm{mol} \cdot \mathrm{m}^{-2} \cdot \mathrm{s}^{-1}$ and a 16-h photoperiod. The grasses were mowed to a height of $6 \mathrm{~cm}$ when they grew to a height of $8 \mathrm{~cm}$. Subsequently, the grasses were mowed in the morning after every $3 \mathrm{~d}$ to keep a height of $6 \mathrm{~cm}$.

At the same time, Hoagland nutrient was sprayed on the soil media during the afternoon after every $3 \mathrm{~d}$. The preparation of nutrient solution was with distilled water and composed of $2.5 \mathrm{mmol} \cdot \mathrm{L}^{-1}$ potassium nitrate $\left(\mathrm{KNO}_{3}\right), 0.5 \mathrm{mmol} \cdot \mathrm{L}^{-1}$ ammonium dihydrogen phosphate $\left(\mathrm{NH}_{4} \mathrm{H}_{2} \mathrm{PO}_{4}\right), 2.5 \mathrm{mmol} \cdot \mathrm{L}^{-1}$ calcium nitrate tetrahydrate $\left[\mathrm{Ca}\left(\mathrm{NO}_{3}\right) 2 \cdot 4 \mathrm{H}_{2} \mathrm{O}\right]$, and $1.0 \mathrm{mmol} \cdot \mathrm{L}^{-1} \mathrm{mag}-$ nesium sulfate heptahydrate $\left(\mathrm{MgSO}_{4} \cdot 7 \mathrm{H}_{2} \mathrm{O}\right)$ as macronutrients. The detailed composition of micronutrients was according to the instructions on the Hoagland's nutrient solution protocols (Hoagland and Arnon, 1950). The water lost as a result of direct evaporation was restored every $2 \mathrm{~d}$.

After a perennial ryegrass canopy covered the PVC tubes ( $\approx 2$ months since germination), the rubberized fabric between the joints of PVC tubes was torn apart, and the PVC tubes were cut into three segments. Roots from different parts were cleaned with tap water to remove surface deposits and then blotted to 
dryness. The sampling of roots was conducted daily after every $4 \mathrm{~h}$, to minimize the impact of diurnal variation. Subsequently, roots were separated into two portions: one for analysis as fresh material and the other for analysis as dry material. For the former, either the root length and root activity were determined on the spot, or the samples frozen in liquid nitrogen then stored at $-70^{\circ} \mathrm{C}$ until analysis for free amino acids. For the latter, the roots were killed at $105^{\circ} \mathrm{C}$ for $5 \mathrm{~min}$ and then dried at $80^{\circ} \mathrm{C}$ for $48 \mathrm{~h}$ until they achieved a constant weight. The dry root samples were used to determine the content of soluble sugars.

Treatments and experiment Design. PVC tubes were divided into three layers according to different depths: top, middle, and bottom (Fig. 1). Both the top and the middle layers were $10 \mathrm{~cm}$ deep, whereas the bottom layer was $20 \mathrm{~cm}$ deep. A rubberized fabric was used to link the three segments. Perennial ryegrass was subjected to three levels of saline soil $(0-, 20-$, and 30-cm depths of saline soil).

The three treatments were as follows: 1) A 40-cm-deep mixture of sand and peat ( 7 sand : 3 peat wt/wt) as control, 2) a 20-cm-deep layer of saline soil covered with a 20 -cm-deep mixture of sand and peat as T20, and 3) a 30-cm-deep layer of salt-containing soil covered with a 10-cm-deep mixture of sand and peat as T30. When a perennial canopy had covered the PVC tubes, roots were harvested for physiological analysis. The saline soil treatments were arranged in a randomized complete block design with five replicates.

Measurements. The root length, root diameter, and rootprojected area were estimated as described in a previous study (Mohammad et al., 1998) with little modification. After weighing, the fresh roots (1/6 of total roots) were immersed and soaked in formalin acetic acid (FAA) for fixation. In this study, the materials were soaked in $20 \mathrm{~mL}$ of FAA fixative for $24 \mathrm{~h}$. After $24 \mathrm{~h}$, the materials were retrieved from the tubes and blotted to dryness with filter papers before coloring with Coomassie brilliant blue (R-250; Bio-Rad Laboratories, Hercules, CA) for $48 \mathrm{~h}$. The colored materials were flushed with tap water and blotted dry. They were then laid uniformly on a clear glass panel, using a ruler as the reference system, before taking photos. Finally, Digimizer (MedCalc Software, Osted, Belgium), a software for photo analysis was used to measure the root length and the root-projected area. The total root length and root-projected area were the sums from the different layers (top, middle, and bottom) of roots. The mean root diameter measurement corresponded to Eq. [1] (Pohl et al., 2011; Smit et al., 2013)

$$
\text { Mean root diameter }=\frac{\text { Root }- \text { projected area }}{\text { Root length }}
$$

Root activity was detected with the triphenyl tetrazolium chloride (TTC) method (Chen et al., 2008; Lutts et al., 2004). Fresh roots were precisely weighed $(500 \mathrm{mg})$, cut into pieces, and placed in $25-\mathrm{cm}^{3}$ flasks. After that, $4 \mathrm{~mL}$ of $0.6 \%$ TTC solution, $6 \mathrm{~mL}$ of $0.0667 \mathrm{M}$ phosphate buffer, and $0.05 \%(\mathrm{v} / \mathrm{v})$ wetting agent Tween 20 (Croda Intl., Snaith, UK) were added gradually and mixed adequately. The flasks were then kept at $30{ }^{\circ} \mathrm{C}$ in the dark for $20 \mathrm{~h}$. The colored root samples were blotted dry and placed in $25-\mathrm{cm}^{3}$ tubes followed by addition of $10 \mathrm{~mL} 95 \%$ ethanol. The tubes were then transferred to a water bath of $60^{\circ} \mathrm{C}$ for $4 \mathrm{~h}$ until the roots turned white. A record of the extract solution's absorbance was taken at $530 \mathrm{~nm}$, and the calculation of root activity was according to a standard curve using Eq. [2] (Deng and Zeng, 2015):

$$
\begin{aligned}
& \text { Root activity }\left(\mu \mathrm{g} \cdot \mathrm{g}^{-1} \cdot \mathrm{h}^{-1}\right) \\
& =\frac{\mathrm{TTC} \text { reduction amount in micrograms }}{\text { Fresh root weight in grams } \times \text { Time in hours }} .
\end{aligned}
$$

where $\mu \mathrm{g}$ represents the deoxidizing amount of the TTC in micrograms, $g$ accounts for the fresh weight of roots in grams, and $h$ represents the time of coloration in hours.

Free amino acids were determined by the method of Zhang et al. (2012). The liquid-nitrogen-frozen-grass samples of 500 $\mathrm{mg}$ fresh weight were retrieved for free amino acids extraction using $1.5 \mathrm{~mL}$ of $\mathrm{HCl}(0.1 \mathrm{M})$ at $4{ }^{\circ} \mathrm{C}$ for $8 \mathrm{~h}$. Centrifugation of the tubes containing the extract occurred at $16,000 \mathrm{~g}_{\mathrm{n}}$ for $10 \mathrm{~min}$ and, the collected supernatant was centrifuged again at 16,000 $g_{\mathrm{n}}$ for $40 \mathrm{~min}$. The aqueous phase was collected for highperformance liquid chromatography (HPLC) analysis. An eclipse amino acid analysis column $(4.6 \times 150 \mathrm{~mm}, 5 \mu \mathrm{m})$ eluted at $40{ }^{\circ} \mathrm{C}$ with a gradient of solution A [40 mM sodium acid pyrophosphate $\left.\left(\mathrm{NaH}_{2} \mathrm{PO}_{4}, \mathrm{pH} 7.8\right)\right]$ and buffer $\mathrm{B}[45 \%$ (v/v) acetonitrile, $45 \%(\mathrm{v} / \mathrm{v})$ methanol, $10 \%(\mathrm{v} / \mathrm{v}) \mathrm{H}_{2} \mathrm{O}$ ] at a flow rate of $2.0 \mathrm{~mL} \cdot \mathrm{min}^{-1}$ with the following proportions of buffer, B: $0 \mathrm{~min}, 0 \%$; $1.9 \mathrm{~min}, 0 \%$; $18.1 \mathrm{~min}, 57 \%$; $18.6 \mathrm{~min}, 100 \%$; $22.3 \mathrm{~min}, 100 \%$; $23.2 \mathrm{~min}, 0 \%$; $30 \mathrm{~min} 0 \%$ was used to separate the 17 amino acids. An autosampler (Waters Corp., Milford, MA) was used to make precolumn derivatization by mixing $0.5 \mu \mathrm{L}$ sample with $2.5 \mu \mathrm{L}$ boric acid $\left(\mathrm{H}_{3} \mathrm{BO}_{3} 0.4 \mathrm{M}, \mathrm{pH} 10.2\right)$, $0.5 \mu \mathrm{L}$ o-phthalaldehyde $\left(10 \mathrm{mg} \cdot \mathrm{mL}^{-1}\right), 0.5 \mu \mathrm{L}$ fluorenylmethyl chloroformate $\left(5 \mathrm{mg} \cdot \mathrm{mL}^{-1}\right)$, and $14 \mu \mathrm{L} \mathrm{H} \mathrm{H}_{2} \mathrm{O}$. The ultraviolet detection wavelength was $338 \mathrm{~nm}$. Assay of free amino acids was executed on a refractive index detector, and comparison with standards obtained the peak quantity and identity.

The $\mathrm{NaCl}$ content level before and after experiment was established by the method described in Science Notes, Land series-L137, available at the Queensland Government website (Queesland Government, n.d.). EC of the soil measured was first measured using a 1 soil : 5 water suspension (EC 1:5) in the laboratory. Small soil particles ( $5 \mathrm{~g}$ ) were added to a container with $10 \mathrm{~mL}$ distilled water and the volume was topped up to the $15-\mathrm{mL}$ mark before making a final volume of $30 \mathrm{~mL}$. After shaking intermittently for $5 \mathrm{~min}$ and allowing the solution to settle for $5 \mathrm{~min}$, the EC probe was dipped into the solution and the EC readings were taken. Each of the EC reading was multiplied with the constant for $\mathrm{NaCl}$ content in saline soil according to the standard curve $\left(1 \mathrm{dS} \cdot \mathrm{m}^{-1}\right)$ to obtain the total $\mathrm{NaCl}$ present in the different soil layers (Sonon et al., 2015). This procedure was repeated for the three soil layers and done before the experiment and at the end of the experiment using a conductivity meter (3173 COND; Jenco Instruments, Shanghai, China).

Extraction of the carbohydrates (glucose, fructose, and sucrose) from the roots of perennial ryegrass was according to $\mathrm{Fu}$ and Dernoeden (2008). The dry samples were ground in liquid nitrogen and sieved with a 40-mesh sieve. Extraction involved the addition of $1 \mathrm{~mL}$ ethanol $(92 \% \mathrm{v} / \mathrm{v})$ into $0.1 \mathrm{~g}$ of the subsamples followed by fierce shaking for $10 \mathrm{~min}$. The mixture was centrifuged at $20,000 g_{n}$ for $10 \mathrm{~min}$ followed by repeated re-extraction of the residues with the method mentioned above. Evaporation to dryness of the pooled supernatant was achieved in an oven at $40^{\circ} \mathrm{C}$ before resolubilization of the material in $300 \mu \mathrm{L}$ deionized water for extraction of glucose, fructose, and sucrose. About $0.5 \mathrm{~mL}$ of deionized water was added into the extract followed by heating at $100{ }^{\circ} \mathrm{C}$ for $10 \mathrm{~min}$. Enzymolysis of the intermixture with $0.1 \mathrm{~mL} \alpha$-amylase 
$(400 \mathrm{U} / \mathrm{mL})$ and $0.1 \mathrm{~mL}$ starch transglucosylase $(2 \mathrm{U} / \mathrm{mL})$ in $0.4 \mathrm{~mL}$ acetic buffer (200 mM, $\mathrm{pH} 5.1)$ at $55^{\circ} \mathrm{C}$ for $20 \mathrm{~h}$ followed by centrifugation at $20,000 \mathrm{~g}_{\mathrm{n}}$ for $10 \mathrm{~min}$ was done. The supernatant was kept boiling in an acid environment $(1.0 \mathrm{~N}$ sulfuric acid) for 15 min. Neutralization of the cooled mixture with an equal amount of sodium hydroxide $(1.0 \mathrm{~N})$ preceded storage of the mixture at $-20{ }^{\circ} \mathrm{C}$ for further analysis.

Carbohydrates were analyzed with HPLC (LC-20AD; Shimazu, Kyoto, Japan). The HPLC analytic was equipped with a 515 pump, a 717 autosampler, a 2410 refractometer, and an empower software, which are all products of the Waters Corp. The separation of glucose, fructose, and sucrose sugars was on a crest amino column $(4.6 \times 250 \mathrm{~mm}, 5 \mu \mathrm{m})$ and isocratic elution at $40{ }^{\circ} \mathrm{C}$ with the buffer (acetonitrile: $\mathrm{H}_{2} \mathrm{O}=1: 1 \mathrm{v} / \mathrm{v}$ ) at a flow rate of $1.0 \mathrm{~mL} \cdot \mathrm{min}^{-1}$. The assay of carbohydrates was on a refractive index detector, and comparison with standards obtained the peak quantities and the identities.

Statistical analysis. Expression of all results was in the form of averages of the five replicates. Data was analyzed by one-way analysis of variance. Separation of the means with the least significant difference at a 5\% probability level was with SAS (version 9.0 for Windows; SAS Institute, Cary, NC).

\section{Results}

GROWTH OF PERENNIAL RYEGRASS SUBJECTED TO THE THREE DIFFERENT TREATMENTS CONTROL, T20, AND T30. According to the experimental design (Fig. 1), a tube filled with mixtures of



Fig. 1. Experimental design: polyvinyl chloride tubes $(10.5 \mathrm{~cm}$ diameter, $42 \mathrm{~cm}$ depth) were divided into three layers according to different depth: top, middle, and bottom. Top and middle layers were $10 \mathrm{~cm}$ deep, whereas the bottom layer was $20 \mathrm{~cm}$ deep. A rubberized fabric linked the three segments. The three treatments were 1) control, $40 \mathrm{~cm}$ filled with mixtures of sand and peat ( 7 sand : 3 peat wt/wt); 2) T20, 20-cm saline soil covered with $20-\mathrm{cm}$ sand and peat mixtures; and 3) T30, 30-cm saline soil covered with $10-\mathrm{cm}$ sand and peat mixtures. Black color represents saline soil from the coast of Tianjin, whereas gray color represents the mixture of sand and peat. The control tube has three gray-colored sections (two 10-cm-deep and one 20-cm-deep section), the T20 tube has two gray-colored sections at the top (each $10 \mathrm{~cm}$ deep) and a blackcolored section ( $20 \mathrm{~cm}$ deep) at the bottom, whereas the T30 tube has a graycolored section at the top (10 $\mathrm{cm}$ deep) and a black-colored section at the bottom (middle 10-cm-deep layer and bottom 20-cm-deep layer). The different tubes depict soil salinity at different soil depths as well as varying content of organic matter. Thus, the three different tubes enable observation of the behavior of perennial ryegrass roots subjected to salinity at different soil depths as well as the effect of organic matter on roots at the top-soil layers when bottom soil layers are saline. Every treatment had five replicates. sand and peat to the depth of $40 \mathrm{~cm}$ ( 7 sand : 3 peat wt/wt) was the control, a 20-cm-deep layer of saline soil covered with a 20-cm-deep layer of sand-peat mixture was the T20 and a $30-\mathrm{cm}-$ deep layer of saline soil covered with a $10-\mathrm{cm}$-deep mixture of sand and peat was the T30. All the tubes were $42 \mathrm{~cm}$ deep. The perennial ryegrass grown at T30 exhibited a lower level of both root fresh weight and root dry weight than that grown at both the control and the T20 regimes (Fig. 2). Except for the bottom layer $(20-40 \mathrm{~cm})$, both the fresh and dry weight differences between T20 and the control regimes were insignificant. The total root length of the plants grown at T30 regime was 30.0\% and $24.3 \%$ lower than that in the control and T20 regimes, respectively (Table 1). However, there was no significant difference in the root fresh weight and root dry weight between control and T20 regime. The entire root-projected area was $44.9 \%$ and $22.5 \%$ lower than in the control in T30 and T20, respectively (Table 1), and there was a significant difference between the two doses of saline soil treatments. The mean root diameter was $23.8 \%$ lower in T30 and $17.5 \%$ lower in T20 than in the control (Table 1), but no difference occurred between the two doses of saline soil treatments. As a result, root fresh weight and dry weight, total root length, total root-projected area, and root diameter decreased as the depth of saline soil increased.



Fig. 2. Change of root fresh and dry weight of perennial ryegrass subjected to salinity at different soil depths. Effects of different depth of saline soil on root (A) fresh weight and (B) dry weight of perennial ryegrass. Control represents $40-\mathrm{cm}$-deep sand and peat mixture with no saline soil, T20 represents a 20-cm-deep bottom layer of saline soil covered with a 20 -cm-deep mixture of sand and peat, whereas T30 represents a $30-\mathrm{cm}$-deep bottom layer of saline soil covered with a $10-\mathrm{cm}$-deep layer of sand/peat mixture. The $0-10(\mathrm{~cm})$ represents the topmost soil layer, 10-20 $(\mathrm{cm})$ represents the middle layer, and $20-40(\mathrm{~cm})$ represents the bottommost soil layer. The different letters on the vertical bars indicate the significant statistical differences at $P=0.05$ among the treatments according to the least significant difference test. Similar letters appearing subsequently show insignificant difference while different letters imply significant statistical difference. 
Table 1. Effects of depth of saline soil on total root length, total root-projected area, and average root diameter of perennial ryegrass subjected to control, T20, and T30 salinity treatments.

\begin{tabular}{lccc}
\hline Treatment $^{\mathrm{z}}$ & Root length $^{\mathrm{y}}(\mathrm{cm})$ & Root-projected area $^{\mathrm{y}}\left(\mathrm{cm}^{2}\right)$ & Root diam $^{\mathrm{y}}(\mathrm{cm})$ \\
\hline Control & $6,196.8 \mathrm{a}^{\mathrm{x}}$ & $381.6 \mathrm{a}$ & $0.063 \mathrm{a}$ \\
T20 & $5,732.4 \mathrm{a}$ & $295.6 \mathrm{~b}$ & $0.052 \mathrm{~b}$ \\
T30 & $4,336.6 \mathrm{~b}$ & $210.4 \mathrm{c}$ & $0.048 \mathrm{~b}$ \\
\hline
\end{tabular}

${ }^{\mathrm{z}}$ Control $=40$-cm-deep sand and peat mixture with no saline soil, T20 $=20$-cm-deep bottom layer of saline soil covered with 20 -cm-deep mixture of sand and peat, T30 $=30-\mathrm{cm}$-deep bottom layer of saline soil covered with $10-\mathrm{cm}$-deep layer of sand-peat mixture.

${ }^{\mathrm{y}}$ Root length $=$ extent of root extension, root-projected area $=$ sum of the area of all root segments divided by the total root length, root diam = cross-sectional length of the roots from the three treatments.

${ }^{\mathrm{x}}$ Lowercase letters within a column show significance difference between treatments based on least significant difference test at $P=0.05$; values with the same lowercase letter along the column are not significantly different while those with different lowercase letters along the column are significantly different.

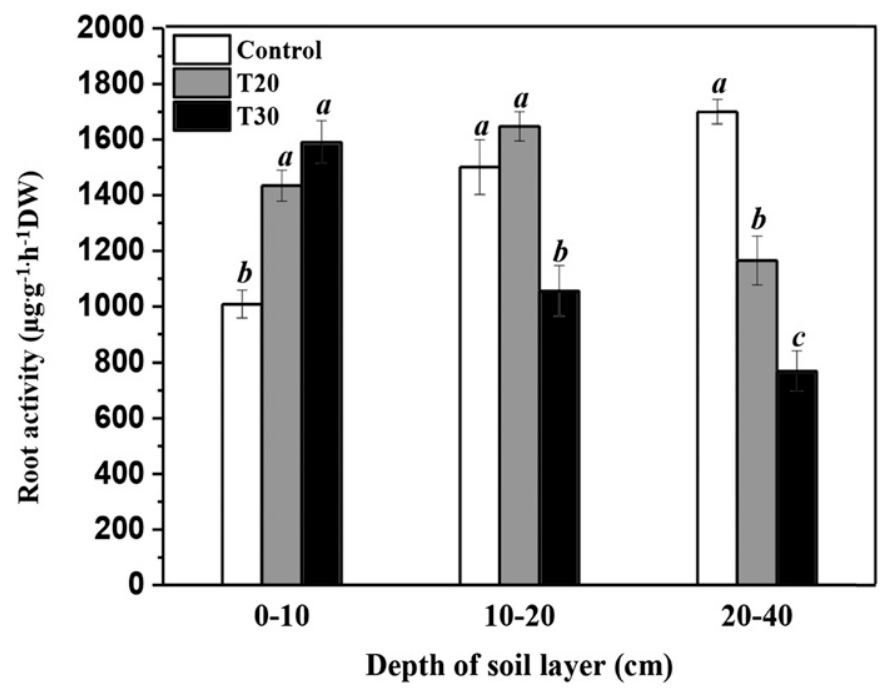

Fig. 3. Effects of soil depth on the root activity of perennial ryegrass subjected to salinity stress at different soil depths. Root activity was calculated as the value of deoxidizing amount of triphenyl tetrazolium chloride (micrograms) divided by the product of root fresh weight (grams) and time of coloration (hours). Control represents 40-cm-deep sand and peat mixture with no saline soil, T20 represents a $20-\mathrm{cm}$-deep bottom layer of saline soil covered with a $20-\mathrm{cm}$ deep mixture of sand and peat, whereas T30 represents a $30-\mathrm{cm}$-deep bottom layer of saline soil covered with a $10-\mathrm{cm}$-deep layer of sand-peat mixture. The 0-10 $(\mathrm{cm})$ represents the topmost soil layer, 10-20 $(\mathrm{cm})$ represents the middle layer, and 20-40 (cm) the bottommost soil layer. The different letters indicate the significant statistical differences at $P=0.05$ among the treatments according to least significant difference test.

Saline soil influenced root activity in the perennial ryegrass exposed to salinity stress (Fig. 3). At the top layer $(0-10 \mathrm{~cm})$, root activity was 1.6-fold higher in T30 and 1.4-fold higher in T20 than in the control, whereas no significant difference between the two doses of saline soil treatments was present. At the middle layer of soil $(10-20 \mathrm{~cm})$, the level of root activity was lower in T30 than in both the control and T20. Remarkably, root activity in this layer $(10-20 \mathrm{~cm})$ in T20 was higher than in the control. At the bottom of the soil $(20-40 \mathrm{~cm})$, root activity decreased with the depth of saline soil. Compared with the control, the two doses of saline soil treatments caused a significant decline in root activity, and the T30 regime had the least root activity of $769 \mu \mathrm{g} \cdot \mathrm{g}^{-1} \cdot \mathrm{h}^{-1}$. The presence of saline soil could have induced the change in root activity. Meanwhile, the roots sampled from the different soil layers in the same regime had a varying extent of root activity. In the control, root activity increased with soil depth, and root activity in roots from the bottom soil $(20-40 \mathrm{~cm})$ was 1.7 -fold higher than of those from the topsoil $(0-10 \mathrm{~cm})$. In the T20 regime, root activity first increased with soil depth (at 10-20 cm) to a level above the control's and then decreased (at 20-40 cm) with soil depth to a level below the control's. In the T30 system, root activity decreased with soil depth, with the activity at the bottom $(20-40 \mathrm{~cm})$ being only one-third of that at the top $(0-10 \mathrm{~cm})$.

FREe AMINO ACIDS ASSAYED FROM ROOTS OF PERENNIAL RYEGRASS SUBJECTED TO CONTROL, T20, AND T30 TREATMENTS. Aspartic acid (Asp), Glu, Ser, Gly, threonine, Arg, Alanine, methionine, leucine, and lysine were assayed (Table 2). The results indicate that except for Arg and Lys, the content of the other free amino acids in T30 was significantly higher than that in T20 and control. However, there was no significant difference in the content of free amino acids between the control and the T20. Asp, Glu, Ser, and Arg had a higher accumulation than the other free amino acids measured in this study. The accumulation of glutamine and Gly primarily caused the remarkable increase of free amino acids in T30; their levels increased up to 2- and 3-fold when compared with their concentrations in the control. Overall, the content of free amino acids increased as the depth of saline soil increased.

NACL CONTENT IN SOIL BEFORE SOWING AND AFTER HARVESTING OF PERENNIAL RYEGRASS IN THE CONTROL, T20, AND T30 REgImes. The content of $\mathrm{NaCl}$ before and after the experiment did not change significantly along the three soil layers in the control regime. However, the $\mathrm{NaCl}$ in T20 and T30 increased along soil depth. The increase of $\mathrm{NaCl}$ in the deeper layers after the experiment is attributable to leakage as from the top to the bottom soil. The difference between $\mathrm{NaCl}$ content before and after experiment was significant in the bottom layer of T20 and in the middle and bottom layers of T30 (Table 3).

CARbohydRATE CONCENTRATION IN ROOTS OF PERENNIAL RYEGRASS SUBJECTED TO THE CONTROL, T20, AND T30 REGIMES. The determination of dissolvable sugars (including fructose and glucose as well as sucrose) in root samples from different soil layers was conducted (Fig. 4). Dissolvable sugar content was significantly affected by saline soil, although a detectable difference among the samples may be attributable to soil depth. Three kinds of sugars accumulated as the depth of saline soil increased. In the roots from the top-soil layer $(0-10 \mathrm{~cm})$, the content of glucose was 2.7-fold higher in T30 and 1.8-fold higher in T20 than in the control. Nonetheless, the levels of both fructose and sucrose were 2.0-fold higher in T30 and 1.2-fold higher in T20 than in the control. In the roots from the middle soil layer $(10-20 \mathrm{~cm})$, there was a significant difference in one of the sugars between the two doses of saline soil treatments and the control; the three sugars had a dramatic increase although that of glucose was higher compared with the other two sugars. In the T30 treatment, its level rose up to 5-fold greater than the 
Table 2. Effects of saline-soil depth on the content of free amino acids in the roots of perennial ryegrass from the top layer $(0-10 \mathrm{~cm})$ of the control, T20, and T30 salinity treatments.

\begin{tabular}{lcccccccccc}
\hline & \multicolumn{8}{c}{ Free amino acid content $\left(\mathrm{mg} \cdot \mathrm{g}^{-1} \text { fresh } \mathrm{wt}\right)^{\mathrm{y}}$} \\
\cline { 2 - 11 } Treatment $^{\mathrm{y}}$ & Asp & Glu & Ser & Gly & Thr & Arg & Ala & Met & Leu & Lys \\
\hline Control & $4.14 \mathrm{~b}^{\mathrm{x}}$ & $3.98 \mathrm{~b}$ & $2.93 \mathrm{~b}$ & $1.96 \mathrm{~b}$ & $1.76 \mathrm{~b}$ & $6.84 \mathrm{~b}$ & $1.76 \mathrm{~b}$ & $0.56 \mathrm{~b}$ & $1.17 \mathrm{~b}$ & $1.26 \mathrm{~b}$ \\
T20 & $4.84 \mathrm{~b}$ & $4.73 \mathrm{~b}$ & $3.09 \mathrm{~b}$ & $2.53 \mathrm{~b}$ & $2.36 \mathrm{~b}$ & $7.26 \mathrm{ab}$ & $1.58 \mathrm{~b}$ & $0.66 \mathrm{~b}$ & $1.22 \mathrm{~b}$ & $1.56 \mathrm{ab}$ \\
T30 & $6.24 \mathrm{a}$ & $7.26 \mathrm{a}$ & $4.52 \mathrm{a}$ & $5.28 \mathrm{a}$ & $3.36 \mathrm{a}$ & $8.87 \mathrm{a}$ & $3.22 \mathrm{a}$ & $1.15 \mathrm{a}$ & $1.51 \mathrm{a}$ & $1.85 \mathrm{a}$
\end{tabular}

${ }^{\mathrm{z}}$ Control $=40$-cm-deep sand and peat mixture with no saline soil, T20 $=20$-cm-deep bottom layer of saline soil covered with 20-cm-deep mixture of sand and peat, T30 $=30$-cm-deep bottom layer of saline soil covered with $10-\mathrm{cm}$-deep layer of sand-peat mixture.

${ }^{\mathrm{y}}$ Means of the 10 amino acids assayed from the top layer $(0-10 \mathrm{~cm})$ of the three treatments; Asp $=$ aspartic acid; $\mathrm{Glu}=$ glutamic acid; $\mathrm{Ser}=$ serine; $\mathrm{Gly}=$ glycine; $\mathrm{Thr}=$ threonine; $\mathrm{Arg}=$ arginine; $\mathrm{Ala}=$ alanine; Met $=$ methionine; Leu $=$ leucine; Lys $=$ lysine .

${ }^{\mathrm{x}}$ Lowercase letters within a column show difference between treatments based on least significant difference test at $P=0.05$; values with the same lowercase letter along the column lack significant difference, whereas those with different lowercase letters along the column have significant difference. Letter "b" depicts comparison of T20 and T30 against the control, whereas letter "a" implies comparison of control and T20 against T30. Thus, values with both letters (ab) signify neither significant differences between T20 and control nor between T20 and T30.

Table 3. Differences of soil $\mathrm{NaCl}$ content among the three salinity treatments (control, T20, and T30) and between the soil layers (top, middle, and bottom) of each of the three treatments, in which perennial ryegrass was subjected to, before, and after experiment.

\begin{tabular}{|c|c|c|c|c|c|c|}
\hline \multirow[b]{3}{*}{ Treatment $^{\mathrm{z}}$} & \multicolumn{6}{|c|}{ Total soil solids $(\%)^{\mathrm{y}}$} \\
\hline & \multicolumn{2}{|c|}{$0-10(\mathrm{~cm})$} & \multicolumn{2}{|c|}{$10-20(\mathrm{~cm})$} & \multicolumn{2}{|c|}{$20-40(\mathrm{~cm})$} \\
\hline & Initial & Final & Initial & Final & Initial & Final \\
\hline Control & $0.21 \mathrm{aA}^{\mathrm{x}}$ & $0.23 \mathrm{bA}$ & $0.20 \mathrm{bA}$ & $0.25 \mathrm{cA}$ & $0.21 \mathrm{bA}$ & $0.24 \mathrm{cA}$ \\
\hline $\mathrm{T} 20$ & $0.20 \mathrm{aA}$ & $0.37 \mathrm{bA}$ & $0.21 \mathrm{bB}$ & $0.75 \mathrm{bA}$ & $4.51 \mathrm{aA}$ & $1.39 \mathrm{bB}$ \\
\hline $\mathrm{T} 30$ & $0.20 \mathrm{aB}$ & $0.58 \mathrm{aA}$ & $4.50 \mathrm{aA}$ & $1.93 \mathrm{aB}$ & $4.50 \mathrm{aA}$ & $2.68 \mathrm{aB}$ \\
\hline
\end{tabular}

${ }^{\mathrm{z}}$ Control $=40$-cm-deep sand and peat mixture with no saline soil, T20 $=20$-cm-deep bottom layer of saline soil covered with 20 -cm-deep mixture of sand and peat, T30 $=30-\mathrm{cm}$-deep bottom layer of saline soil covered with $10-\mathrm{cm}$-deep layer of sand/peat mixture.

${ }^{\mathrm{y}}$ The total percentage of $\mathrm{NaCl}$ present in the three different soil layers of the three treatments; 0-10 $(\mathrm{cm})=$ topmost soil layer, $10-20(\mathrm{~cm})=$ middle layer, $20-40(\mathrm{~cm})=$ bottommost soil layer. Columns marked "initial" have values taken at the beginning of the experiment while those marked "final" have values taken at the end of the experiment.

${ }^{x}$ Lowercase letters within a column show significant difference between treatments (Control, T20, and T30) based on least significant difference (LSD) test at $P=0.05$; values with the same lowercase letter along the column are not significantly different, whereas those with different lowercase letters along the column are significantly different. Uppercase letters show significant difference within a row only between the results from the same soil layer before and after experiment based on LSD test at $P=0.05$.

level in the control. In the roots from the bottom soil layer (20$40 \mathrm{~cm}$ ), the contents of glucose, fructose, and sucrose further increased with the increasing depth of the saline soil. In the dry root samples of T30 regime, glucose, fructose, and sucrose contents were $74.2,95.2$, and $109.3 \mathrm{mg} \cdot \mathrm{g}^{-1}$, respectively; a range of concentration that was 3- to 6-fold higher than that in the control.

\section{Discussion}

Our study showed that soil salinity stress at subsurface soil depth inhibited the growth of perennial ryegrass roots. The two doses of saline soil treatments $(20$-cm-deep saline soil covered with 20 -cm-deep mixture as T20, 30-cm-deep saline soil covered with $10-\mathrm{cm}$-deep mixture as T30, where mixture is 7 sand: 3 peat $w t / w t)$, reduced the root biomass of perennial ryegrass. This observation resonates with previous studies that demonstrated that high salinity stunted plant growth by causing both ionic and osmotic stress (Allakhverdiev et al., 2000; Ben
Khaled et al., 2003; Jia et al., 2011; Zhu, 2001). Moreover, it was suggested that high salinity stress had a severe effect that potentially created ionic toxicity and secondary stresses in a plant (Dat et al., 2000; $\mathrm{Hu}$ et al., 2011). Consequently, the plant would have stunted growth and reduced root length and root biomass and eventually, the plant would develop a nutritional disorder and succumb to death (Mohammad et al., 1998; Trapp et al., 2008). The rapid decline of root biomass, total root length, and root diameter in plants grown under the T30 treatment indicates that high salinity stress significantly inhibits the growth of the root system, which is consistent with previous studies (Bilgin et al., 2008; Mohammad et al., 1998). However, the root biomass and the total root length declined by less than $25 \%$, and no striking difference between the control and the T20 was apparent. This observation may suggest that a 20-cm-deep mixture of sand and organic materials, serving as a cushion area, can supply the necessary top-soil layer for root elongation and growth of perennial ryegrass alongside regular spray irrigation when exposed to soil salinity stress at bottom soil layers.

The results of this study also showed that root activity in the bottom soil layer (fully saline soil) drastically declined, but increased significantly in the upper soil layer (filled with mixtures of sand and peat). Root activity is an important physiological indicator to assess the adaptation of plants exposed to stress conditions (Lee et al., 2006; Tamura et al., 1995). Besides, it is essential for root absorption, synthesis, oxidation, and restoration as objective criteria to reflect the growth rate of plants to a certain extent (Clemenssonlindell, 1994). The high root activity indicates a greater ability to absorb water and nutrients and also a faster growth rate (Ruf and Brunner, 2003). The probability of salt stress and ionic toxicity to reduce vigor and activity of the dehydrogenase enzyme in roots has been reported in many studies (Islam et al., 2007; Li et al., 2005). Nevertheless, a past study showed that root activity in three desert halophyte species significantly increased with increased salt concentration (Yi et al., 2007). In this study, root activity in perennial ryegrass surviving in a saline soil condition drastically dropped implying that high salinity decreased root activity. Since the root activity in the mixture of sand and peat was significantly high, this could suggest an adaptive response of perennial ryegrass exposed to extreme soil salinity. The underlying mechanism, in this case, is the metastasis of the active site on roots and a brief period of high density of new roots in the upper soil layer. 

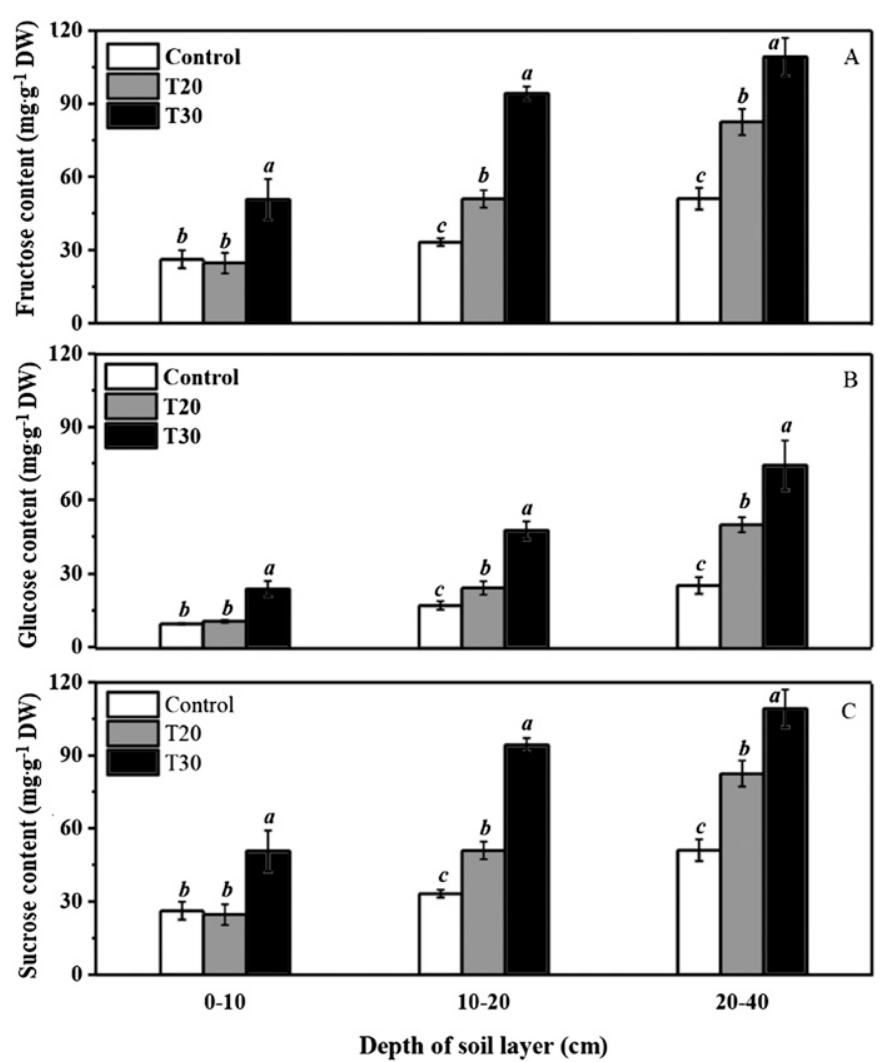

Fig. 4. Relationship between soil depth and sugar concentration in the roots of perennial ryegrass subjected to salinity stress at different soil depths. (A) Fructose, (B) glucose, and (C) sucrose in the roots of perennial ryegrass from different soil layers. Control represents $40-\mathrm{cm}$-deep sand and peat mixture with no saline soil, T20 represents a 20-cm-deep bottom layer of saline soil covered with a $20-\mathrm{cm}$-deep mixture of sand and peat, whereas T30 represents a 30-cm-deep bottom layer of saline soil covered with a 10-cm-deep layer of sand-peat mixture. The $0-10(\mathrm{~cm})$ represents the topmost soil layer, 10-20 $(\mathrm{cm})$ represents the middle layer, and $20-40(\mathrm{~cm})$ the bottommost soil layer. Vertical bars show standard deviation, and bars with the same letters indicate no significant difference at $P=0.05$ for the comparison of treatment at a given depth of soil layer according to least significant difference test.

Our results also revealed an increase in the content of free amino acids in the roots of perennial ryegrass grown in saline soil. In a previous research, amino acids were observed to accumulate in the roots of maize (Zea mays) with rising external salinity concentration (Abd-El Baki et al., 2000).Although in mulberry (Morus alba), the content of free amino acids increased at low salinity levels but decreased at high salinity levels (Agastian et al., 2000). Many studies have reported the functions of free amino acids; in addition to osmoregulation, they scavenge for hydroxyl radicals and act as a sink for energy. They also regulate redox potentials of metabolism, act as nitrogen sources and, as storage compounds for utilization in rapid growth after salinity stress (Matysik et al., 2002; Parida and Das, 2005; Rai, 2002; Sairam et al., 2002). By comparing the levels of single amino acids, our study conspicuously showed significant quantities of Gly and glutamine in perennial ryegrass under study. A remarkable increase of these two amino acids occurred in the roots sampled from the T30 treatment. In previous studies, Glu and Gly were identified as the principal metabolites in the process of chlorophyll synthesis, whereas proline was found to be synthesized mainly from glutamate in plants (Kannangara et al., 1988; Szabados and Savoure, 2010).
The accumulation of both glutamine and Gly in response to high salinity stress suggests their participation in critical physiological-biochemical reactions and their major role in adaptive responses and regulative mechanisms in perennial ryegrass growing in a saline environment.

A strong correlation between soluble sugars accumulation and osmotic stress tolerance has been reported in transgenic plant materials (Taji et al., 2002). The higher carbohydrate concentration before and during the period of abiotic stress may indicate better tolerance (Kafi et al., 2003). Kerepesi and Galiba (2000) also put forward that soluble sugars including fructose, glucose, and sucrose in salinity-stressed plants mainly played a role in osmotic adjustment and osmoprotection as well as carbon storage for energy and metabolism. Another study suggested photosynthate translocation from leaves to roots, degradation of high molecular compound, and self-synthesis as the source of soluble sugars in plant roots (Robbins and Pharr, 1988). Although some researchers reported suppression of photosynthesis upon exposure to salt stress (Kao et al., 2001; Soussi et al., 1998), in contrast, other studies disapprove photosynthesis inhibition due to salinity stress. Moreover, it has also been reported that low salinity stimulates photosynthesis (Kurban et al., 1999; Rajesh et al., 1998). Salinity stress induces accumulation of soluble sugars, which may prevent major metabolic changes hence contributing toward a plant's tolerance to salinity (Pattanagul and Thitisaksakul, 2008).

Our study reveals that soil salinity at bottom soil layers induced the accumulation of soluble sugars in the roots of perennial ryegrass and, their concentration differed with the depth of the soil. The content of fructose, glucose, and sucrose went up as the depth of saline soil increased; the roots from the bottom soil layer (full of saline soil) showed a higher sugar accumulation than the roots from the upper soil layer (filled with mixtures of sand and organic materials). In this study, water was sprayed every $2 \mathrm{~d}$ to replace water loss. Perennial ryegrass exhibited an exceptional turf quality (its score ranged between 8 and 9 while full score is 10) without leaf death. Since the leaves lacked visible morphological damage, we speculated that photosynthesis might have been only slightly or unaffected at all. The root system is the first site to encounter salinity stress present at bottom soil layers due to root elongation and growth. Consequently, the roots made the initial adaptive responses to cope with the stressful environment.

Furthermore, the upper soil layer had lower salinity content, whereas the bottom soil layer had a higher salinity concentration due to water leakage from topsoil to bottom soil (Table 3). The high salinity concentration inhibited new root growth and led to the accumulation of metabolites. Soluble sugars might have enabled osmotic adjustment and osmoprotection from salinity stress. In addition, they might have supplied carbon for metabolism to prepare adequate metabolic products and energy for root growth after salinity stress.

In summary, the perennial ryegrass subjected to saline soil treatments in this study experienced tissue damage. Under extreme salinity stress at the bottommost soil, both the growth and elongation of roots were inhibited culminating in thin root systems with significantly low root biomass. Similarly, the concentration of free amino acids and soluble sugars in roots increased. Root activity in the bottommost soil layer (composed of extremely saline soil) dropped drastically; however, the root activity in the upper soil layer (filled with mixtures of sand and organic materials) significantly increased. The accumulation of 
soluble solutes in the roots exposed to the saline soil layer, increased root activity and high content of free amino acids in roots sampled from the nonsaline-soil layer represents the adaptive responses and regulative mechanisms in perennial ryegrass to cope with severe soil salinity stress conditions. These results further support a top layer of 20-cm-deep mixture of sand and organic materials hypothesis for the root growth of perennial ryegrass exposed to acute soil salinity stress when combined with regular spray irrigation.

\section{Literature Cited}

Abd-El Baki, G.K., F. Siefritz, H.M. Man, H. Weiner, R. Kaldenhoff, and W.M. Kaiser. 2000. Nitrate reductase in Zea mays L. under salinity. Plant Cell Environ. 23:515-521.

Agastian, P., S.J. Kingsley, and M. Vivekanandan. 2000. Effect of salinity on photosynthesis and biochemical characteristics in mulberry genotypes. Photosynthetica 38:287-290.

Allakhverdiev, S.I., A. Sakamoto, Y. Nishiyama, M. Inaba, and N. Murata. 2000. Ionic and osmotic effects of NaCl-induced inactivation of photosystems I and II in Synechococcus sp. Plant Physiol. 123:1047-1056.

Barnett, N.M. and A.W. Naylor. 1966. Amino acid and protein metabolism in bermuda grass during water stress. Plant Physiol. 41:1222-1230.

Ben Khaled, L., A.M. Gomez, E.M. Ouarraqi, and A. Oihabi. 2003. Physiological and biochemical responses to salt stress of mycorrhized and/or nodulated clover seedlings (Trifolium alexandrinum L.). Agronomie 23:571-580.

Bilgin, O., I. Baser, K.Z. Korkut, A. Balkan, and N. Saglam. 2008. The impacts on seedling root growth of water and salinity stress in maize (Zea mays indentata Sturt.). Bulg. J. Agr. Sci. 14:313-320.

Chen, Z., X. Wang, Z. Feng, F. Zheng, X. Duan, and W. Yang. 2008. Effects of elevated ozone on growth and yield of field-grown rice in Yangtze River Delta, China. J. Environ. Sci. (China) 20:320-325.

Cheong, M.S. and D.J. Yun. 2007. Salt-stress signaling. J. Plant Biol. 50:148-155.

Clemenssonlindell, A. 1994. Triphenyltetrazolium chloride as an indicator of fine-root vitality and environmental-stress in coniferous forest stands: Applications and limitations. Plant Soil 159:297-300.

Dat, J., S. Vandenabeele, E. Vranova, M. Van Montagu, D. Inze, and F.

Van Breusegem. 2000. Dual action of the active oxygen species during plant stress responses. Cell. Mol. Life Sci. 57:779-795.

Di Martino, C., S. Delfine, R. Pizzuto, F. Loreto, and A. Fuggi. 2003. Free amino acids and glycine betaine in leaf osmoregulation of spinach responding to increasing salt stress. New Phytol. 158:455463.

Deng, O.X. and D.F. Zeng. 2015. Physicochemical property testing of a novel maize seed coating agent and its antibacterial mechanism research. Open J. Soil Sci. 5:45-52.

Farooq, M., A. Wahid, D.J. Lee, O. Ito, and K.H.M. Siddique. 2009. Advances in drought resistance of rice. Crit. Rev. Plant Sci. 28:199217.

Fu, J. and P.H. Dernoeden. 2008. Carbohydrate metabolism in creeping bentgrass as influenced by two summer irrigation practices. J. Amer. Soc. Hort. Sci. 133:678-683.

Gilbert, G.A., M.V. Gadush, C. Wilson, and M.A. Madore. 1998. Amino acid accumulation in sink and source tissues of Coleus blumei Benth during salinity stress. J. Expt. Bot. 49:107-114.

Greenway, H. and R. Munns. 1980. Mechanisms of salt tolerance in non-halophytes. Annu. Rev. Plant Physiol. Plant Mol. Biol. 31:149 190.

Gupta, P.K. 2001. Methods in environmental analysis: Water, soil, and air. 2nd ed. Agrobios, Jodhpur, India.

Hasegawa, P.M., R.A. Bressan, J.K. Zhu, and H.J. Bohnert. 2000. Plant cellular and molecular responses to high salinity. Annu. Rev. Plant Physiol. Plant Mol. Biol. 51:463-499.
Hoagland, D.R. and D.I. Arnon. 1950. The water-culture method for growing plants without soil. California Agr. Expt. Sta. Circ. 347.

Hu, T., H.Y. Li, X.Z. Zhang, H.J. Luo, and J.M. Fu. 2011. Toxic effect of $\mathrm{NaCl}$ on ion metabolism, antioxidative enzymes and gene expression of perennial ryegrass. Ecotoxicol. Environ. Saf. 74:2050-2056.

Islam, E., X. Yang, T.Q. Li, D. Liu, X.F. Jin, and F.H. Meng. 2007. Effect of $\mathrm{Pb}$ toxicity on root morphology, physiology and ultrastructure in the two ecotypes of Elsholtzia argyi. J. Harzadious Materials 147:806-816.

Jia, J., X.J. Cui, J.H. Wu, J.Y. Wang, and G.Z. Wang. 2011. Physiological and biochemical responses of halophyte Kalidium foliatum to salt stress. Afr. J. Biotechnol. 10:11468-11476.

Kafi, M., W.S. Stewart, and A.M. Borland. 2003. Carbohydrate and proline contents in leaves, roots, and apices of salt-tolerant and saltsensitive wheat cultivars. Russ. J. Plant Physiol. 50:155-162.

Kannangara, C.G., S.P. Gough, P. Bruyant, J.K. Hoober, A. Kahn, and D. Vonwettstein. 1988. Transfer Rna-Glu as a cofactor in deltaaminolevulinate biosynthesis: Steps that regulate chlorophyll synthesis. Trends Biochem. Sci. 13:139-143.

Kao, W.Y., H.C. Tsai, and T.T. Tsai. 2001. Effect of $\mathrm{NaCl}$ and nitrogen availability on growth and photosynthesis of seedlings of a mangrove species, Kandelia candel (L.) Druce. J. Plant Physiol. 158:841-846.

Kerepesi, I. and G. Galiba. 2000. Osmotic and salt stress-induced alteration in soluble carbohydrate content in wheat seedlings. Crop Sci. 40:482-487.

Kerkeb, L. and U. Kramer. 2003. The role of free histidine in xylem loading of nickel in Alyssum lesbiacum and Brassica juncea. Plant Physiol. 131:716-724.

Koca, H., M. Bor, F. Ozdemir, and I. Turkan. 2007. The effect of salt stress on lipid peroxidation, antioxidative enzymes and proline content of sesame cultivars. Environ. Expt. Bot. 60:344-351.

Kurban, H., H. Saneoka, K. Nehira, R. Adilla, G.S. Premachandra, and K. Fujita. 1999. Effect of salinity on growth, photosynthesis and mineral composition in leguminous plant Alhagi pseudoalhagi (Bieb.). Soil Sci. Plant Nutr. 45:851-862.

Lee, S.H., J.H. Choi, W.S. Kim, T.H. Han, Y.S. Park, and H. Gemma. 2006. Effect of soil water stress on the development of stone cells in pear (Pyrus pyrifolia cv. 'Niitaka') flesh. Sci. Hort. 110:247-253.

Li, T.Q., X.E. Yang, X.F. Jin, Z.L. He, P.J. Stoffella, and Q.H. Hu. 2005. Root responses and metal accumulation in two contrasting ecotypes of Sedum alfredii Hance under lead and zinc toxic stress. J. Environ. Sci. Health 40:1081-1096.

Lutts, S., M. Almansouri, and J.M. Kinet. 2004. Salinity and water stress have contrasting effects on the relationship between growth and cell viability during and after stress exposure in durum wheat callus. Plant Sci. 167:9-18.

Masterton, W.L., C.W. Hurley, and E. Neth. 2011. Chemistry: Principles and reactions. 7th ed. Cengage Learning, Boston, MA.

Matysik, J., A. Alia, B. Bhalu, and P. Mohanty. 2002. Molecular mechanisms of quenching of reactive oxygen species by proline under stress in plants. Curr. Sci. 82:525-532.

Mohammad, M., R. Shibli, M. Ajlouni, and L. Nimri. 1998. Tomato root and shoot responses to salt stress under different levels of phosphorus nutrition. J. Plant Nutr. 21:1667-1680.

Munns, R. 2002. Comparative physiology of salt and water stress. Plant Cell Environ. 25:239-250.

Munns, R. 2005. Genes and salt tolerance: Bringing them together. New Phytol. 167:645-663.

Munns, R. and M. Tester. 2008. Mechanisms of salinity tolerance. Annu. Rev. Plant Biol. 59:651-681.

Parida, A.K. and A.B. Das. 2005. Salt tolerance and salinity effects on plants: A review. Ecotoxicol. Environ. Saf. 60:324-349.

Pattanagul, W. and M. Thitisaksakul. 2008. Effect of salinity stress on growth and carbohydrate metabolism in three rice (Oryza sativa L.) cultivars differing in salinity tolerance. Indian J. Expt. Biol. 46:736742. 
Pohl, M., R. Stroude, A. Buttler, and C. Rixen. 2011. Functional traits and root morphology of alpine plants. Ann. Bot. (Lond.) 108:537-545.

Queesland Government. n.d. Measuring salinity. Science notes. Land Ser. L137. 18 June 2015. <https://publications.qld.gov.au/storage/f/ 2015-01-16T07\%3A02\%3A48.218Z/sn-1137-measuring-salinity. $\mathrm{pdf} />$.

Rai, V.K. 2002. Role of amino acids in plant responses to stresses. Biol. Plant. 45:481-487.

Rajesh, A., R. Arumugam, and V. Venkatesalu. 1998. Growth and photosynthetic characteristics of Ceriops roxburghiana under $\mathrm{NaCl}$ stress. Photosynthetica 35:285-287.

Robbins, N.S. and D.M. Pharr. 1988. Effect of restricted root growth on carbohydrate metabolism and whole plant growth of Cucumis sativus L. Plant Physiol. 87:409-413.

Rolland, F., E. Baena-Gonzalez, and J. Sheen. 2006. Sugar sensing and signaling in plants: Conserved and novel mechanisms. Annu. Rev. Plant Biol. 57:675-709.

Ruf, M. and I. Brunner. 2003. Vitality of tree fine roots: Reevaluation of the tetrazolium test. Tree Physiol. 23:257-263.

Sairam, R.K., K.V. Rao, and G.C. Srivastava. 2002. Differential response of wheat genotypes to long term salinity stress in relation to oxidative stress, antioxidant activity and osmolyte concentration. Plant Sci. 163:1037-1046.

Serraj, R. and T.R. Sinclair. 2002. Osmolyte accumulation: Can it really help increase crop yield under drought conditions? Plant Cell Environ. 25:333-341.

Shrivastava, P. and R. Kumar. 2014. Soil salinity: A serious environmental issue and plant growth promoting bacteria as one of the tools for its alleviation. Saudi J. Biol. Sci. 22:123-131.

Smit, A.L., A.G. Bengough, C. Engels, M. van Noordwijk, S. Pellerin, and S.C. van de Geijn. 2013. Root methods: A handbook. 1st ed. Springer, Berlin, Germany.

Sonon, L.S., U. Saha, and D.E. Kissel. 2015. Soil salinity testing, data interpretation and recommendations. Agricultural and environmental services laboratories. 18 June 2015. <http://extension.uga.edu/ publications/files/pdf/C\%201019_3.PDF/>.

Soussi, M., A. Ocana, and C. Lluch. 1998. Effects of salt stress on growth, photosynthesis and nitrogen fixation in chick-pea (Cicer arietinum L.). J. Expt. Bot. 49:1329-1337.
Szabados, L. and A. Savoure. 2010. Proline: A multifunctional amino acid. Trends Plant Sci. 15:89-97.

Taji, T., C. Ohsumi, M. Seki, S. Iuchi, K. Yamaguchi-Shinozaki, and K. Shinozaki. 2002. Important roles of drought- and cold-inducible genes for galactinol synthase in stress tolerance in Arabidopsis thaliana. Plant Cell Physiol. 29:417-426.

Takahashi, M., H. Nakanishi, S. Kawasaki, N.K. Nishizawa, and S. Mori. 2001. Enhanced tolerance of rice to low iron availability in alkaline soils using barley nicotianamine aminotransferase genes. Nat. Biotechnol. 19:466-469.

Tamura, F., K. Tanabe, and M. Katayama. 1995. Relationship between water tolerance and cyanide-resistant respiration in pear rootstocks. J. Jpn. Soc. Hort. Sci. 64:47-53.

Trapp, S., D. Feificova, N.F. Rasmussen, and P. Bauer-Gottwein. 2008. Plant uptake of $\mathrm{NaCl}$ in relation to enzyme kinetics and toxic effects. Environ. Expt. Bot. 64:1-7.

Turkan, I. and T. Demiral. 2009. Recent developments in understanding salinity tolerance. Environ. Expt. Bot. 67:2-9.

Verslues, P.E. and R.E. Sharp. 1999. Proline accumulation in maize (Zea mays L.) primary roots at low water potentials. II. Metabolic source of increased proline deposition in the elongation zone. Plant Physiol. 119:1349-1360.

Wilkins, P.W. and M.O. Humphreys. 2003. Progress in breeding perennial forage grasses for temperate agriculture. J. Agr. Sci. 140: $129-150$

Xing, Y., U. Frei, B. Schejbel, T. Asp, and T. Lubberstedt. 2007. Nucleotide diversity and linkage disequilibrium in 11 expressed resistance candidate genes in Lolium perenne. BMC Plant Biol. 7:43.

Xiong, Y.W., S.Z. Fei, R. Arora, E.C. Brummer, R.E. Barker, G.W. Jung, and S.E. Warnke. 2007. Identification of quantitative trait loci controlling winter hardiness in an annual $\times$ perennial ryegrass interspecific hybrid population. Mol. Breed. 19:125-136.

Yi, L.P., J. Ma, and Y. Li. 2007. Impact of salt stress on the features and activities of root system for three desert halophyte species in their seedling stage. Sci. China Ser. D. 50:97-106.

Zhang, P.P., J.M. Fu, and L.X. Hu. 2012. Effects of alkali stress on growth, free amino acids and carbohydrates metabolism in kentucky bluegrass (Poa pratensis). Ecotoxicology 21:1911-1918.

Zhu, J.K. 2001. Plant salt tolerance. Trends Plant Sci. 6:66-71. 